\title{
SISTEM INFORMASI E-VOTING PEMILIHAN KETUA DAN WAKIL KETUA SENAT MAHASISWA BERBASIS WEB MENGGUNAKAN FRAMEWORK CODEIGNITER UNTUK MENINGKATKAN EFEKSTIFITAS DAN EFISIENSI DI MASA PANDEMI - STUDI KASUS DI STIKOM YOS SUDARSO PURWOKERTO
}

\author{
Antonius Ary Setyawan ${ }^{1}$ \\ ${ }^{1}$ Sekolah Tinggi Ilmu Komputer Yos Sudarso PURWOKERTO \\ 1 $\underline{\text { arysetpr@stikomyos.ac.id }}$
}

\begin{abstract}
Abstrak
Voting adalah salah satu metode yang sudah sangat familiar untuk mengambil keputusan bersama dalam kehidupan sosial kemasyarakatan. Dalam konteks pemilihan ketua dan wakil ketua senat mahasiswa, saat situasi normal, hal tersebut bisa dilakukan dengan cara pemilihan langsung yaitu dengan cara mencoblos kertas yang disediakan oleh panitia. Tetapi, dalam masa pandemi Covid-19 ini kita perlu mencari cara lain menggunakan media teknologi informasi. Peluang ini menumbuhkan kreatifitas untuk menciptakan sebuah sistem informasi $E$-voting yang bisa mengatasi persoalan akibat tidak bisanya dilakukan pemilu langsung. Sistem ini diharapkan bisa membantu proses sosialisasi dan kampanye, delivery surat suara, meminimalisir kecurangan, dan sekaligus juga memudahkan perhitungan suara. Tujuan dari penelitian ini adalah mengkaji secara ilmiah ide kreatif di masa pandemi Covid 19 untuk menghasilkan sistem informasi pemilihan umum (E-voting) untuk memilih ketua dan wakil ketua senat mahasiswa dan sekaligus untuk membantu perhitungan rekapitulasi surat suara secara cepat. Sistem yang dibangun dalam penelitian ini berbasis web dan menggunakan framework Codeigniter. Penelitian ini mengambil locus studi kasus di Sekolah Tinggi Ilmu Kompter (STIKOM) Yos Sudarso Purwokerto, Jawa Tengah.
\end{abstract}

Kata kunci : E-voting, Framework Codeigniter, STIKOM Yos, Pemilu Ketua Senat

\section{PENDAHULUAN}

\subsection{Latar Belakang Penelitian}

Peristiwa pandemi Covid-19 di Indonesia yang mewabah sejak tanggal 2 Maret 2020 telah membawa dampak di bidang ekonomi, sosial, politik, budaya, hukum, dan juga pendidikan. Dalam dunia pendidikan tinggi, pandemi Covid 19 ini menuntut kita untuk merumuskan ulang model pembelajaran dan aktifitas akademik yang semula bisa dilakukan secara luring sekarang semua harus dilakukan secara daring atau online. Ketidakmampuan beradaptasi dan ketidaksiapan kita untuk menghadapi dampak Covid-19 ini akan berakibat pada turunnya kinerja perguruan tinggi tersebut [4]. Demokrasi di dalam konteks dunia pendidikan pun tidak luput dari pengaruh pandemi Covid-19 ini. Salah satu yang nampak jelas adalah terkait dengan pemilihan umum untuk memilih ketua dan wakil ketua senat mahasiswa yang perannya sangat signifikan dalam sebuah perguruan tinggi [5].

Sekolah Tinggi Ilmu Komputer-STIKOM Yos Sudarso (SYS) adalah sebuah perguruan tinggi swasta yang berlokasi di kota Purwokerto. Sesuai dengan namanya, SYS Purwokerto merupakan kampus yang memfokuskan diri pada pengajaran ilmu komputer. Dalam salah satu bagian dari visi STIKOM dituliskan bahwa adalah STIKOM Yos Sudarso bercita-cita menjadi Cyber Academic Community yang mempunyai keunggulan dalam pengembangan teknologi informasi. Visi tersebut mempunyai makna penting dimana salah satu faktor keberhasilan organisasi kampus adalah dapat 
mengikuti perkembangan zaman bidang teknologi informasi yang handal, mampu menguasai dan beradaptasi dengan perkembangan teknologi informasi di era Revolusi Industri 4.0.

Salah satu organisasi mahasiswa yang berada di kampus pada umumnya adalah organisasi Senat. Senat mahasiswa STIKOM Yos Sudarso Purwokerto setiap tahun memilih ketua dan wakil ketua senat yang akan bertugas menjadi senat baru pada periode berikutnya dengan masa jabatan selama 1 (satu) tahun. Pada tahun 2015 sampai dengan tahun 2019, proses pemilihan dilakukan dengan cara konvensional. Proses pada saat pemilihan ketua dan wakil ketua senat sebelumnya yaitu dengan cara mencoblos kertas yang diberikan oleh panitia. Proses pencoblosan tersebut dilakukan di tempat tertutup yang sudah ditentukan oleh panitia.

Mencermati model pemilihan selama 3 periode tersebut di atas dan didukung dengan situasi pandemi Covid-19 ini, model pemilihan ketua dan wakil ketua yang dilakukan masih di SYS Purwokerto perlu dievaluasi dan dipikirkan ulang supaya semakin efektif dan efisien serta mampu mengikuti perkembangan zaman bidang teknologi informasi. Evaluasi yang ditemukan dari terhadap model pemilihan yang konvensional adalah bahwa model pemilihan konvsensional tidak bisa dilakukan lagi karena pandemi Covid-19 ini tidak memungkinkan para mahasisiwa untuk datang ke kampus mengingat diberlakukannya kebijakan study from home. Selain itu pada saat proses perhitungan pemilihan konvesnional juga panitia harus menghitung manual jumlah suara yang masuk dan memakan lebih banyak waktu serta menyisakan sampah kertas hasil pemungutan suara tersebut sehingga dengan cara tersebut dinilai masih kurang efektif dan efisien.

Mempertimbangkan beberapa permasalahan di atas dan kesadaran bahwa kegiatan kemahasiswaan di kampus harus tetap berlangsung serta didukung dengan perkembangan teknologi informasi yang sangat cepat, relevan, akurat dan tepat waktu, maka peneliti merumuskan permasalahan penelitiannya sebagai berikut: Bagaimana menciptakan sebuah sistem informasi electronic voting (E-voting) untuk pemilihan ketua dan wakil ketua senat mahasiswa berbasis web.

\subsection{Tujuan dan Manfaat Penelitian}

Tujuan dari penelitian ini adalah untuk mengkaji secara ilmiah ide kreatif di masa pandemi Covid 19 dan menghasilkan sistem informasi pemilihan umum (E-voting) untuk memilih ketua dan wakil ketua senat mahasiswa dan sekaligus untuk membantu perhitungan rekapitulasi surat suara secara cepat. Manfaat dari penelitian ini adalah:

1. Mengekplorasi ide secara kritis, kreatif, dan inovatif untuk menjawab permasalahan yang timbul dalam dunia pendidikan tinggi akibat dampak Pandemi Covid-19 khususnya dalam kaitannya dengan model pemilihan umum senat mahasiswa.

2. Membantu proses sosialisasi dan kampanye, delivery surat suara, meminimalisir kecurangan, dan sekaligus juga memudahkan rekapitulasi perhitungan suara dengan menggunakan Sistem Informasi Pemilihan (E-voting) Ketua dan Wakil Ketua Senat Mahasiswa.

3. Sebagai bahan referensi dan sumber belajar bagi penelitian terkait berikutnya.

4. Mendukung dalam perwujudan visi STIKOM YOS Sudarso untuk menjadikan kampus sebagai Cyber Academic Community.

\subsection{Metode Penelitian}

Metode dalam penelitian ini menggunakan metode prototipe. Model prototipe (prototype model) merupakan model yang digunakan untuk menyambungkan ketidakpahaman user dalam hal masalah teknis serta memperjelas spesifikasi kebutuhan yang diinginkan oleh user terhadap pengembang perangkat lunak (Shalahudin \& Sukamto, 2016). Gambar 1 di bawah ini menjelas kan mengenai proses tahap demi tahap dalam pengembangan sistem yang dibangun. 


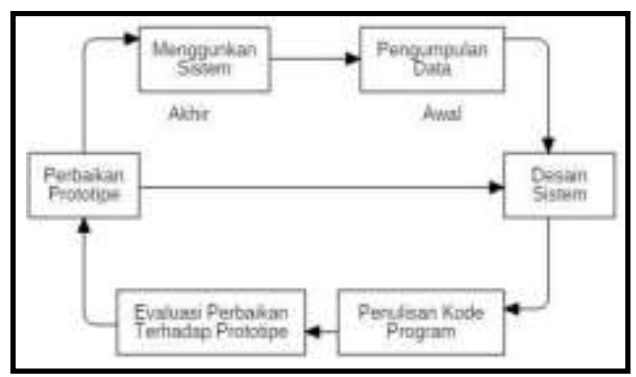

Gambar 1. Metode Prototipe

Metode prototipe dimulai dari pengumpulan kebutuhan pelanggan terhadap perangkat lunak yang akan dibuat. Kemudian akan dibuat program prototipe supaya user mempunyai gambaran tentang apa yang sebenarnya mau dirancang. Program prototipe merupakan program yamg belum jadi yang hanya menyediakan tampilan dengan simulasi alur perangkat lunak sehingga akan tampak seperti perangkat yang sudah jadi. Program prototipe akan terus dievaluasi oleh pelanggan atau user sampai dengan spesifikasi yang diinginkan oleh pelanggan atau user.

\section{DASAR TEORI}

\subsection{Sistem Informasi}

Sistem adalah kumpulan dari prosedur-prosedur yang saling terkait dan terhubung yang dilakukan bersama-sama demi suatu tujuan tertentu. Secara umum, sistem informasi mempunyai tiga komponen utama yang saling terkait yaitu software, hardware dan brainware [7]. Informasi merupakan kumpulan data yang diolah menjadi bentuk yang berguna dalam membuat keputusan. Informasi sebagai pembuat keputusan yang berguna serta menurunkan ketidakpastian (atau pengetahuan semakin berkembang). Informasi merupakan hasil dari pengolahan data atau fakta yang dikumpulkan dengan metode-metode tertentu [6]. Dari dua pengertian diatas kita bisa memahami bahwa sistem informasi merupakan kombinasi dari sesuatu yang teratur meliputi orang-orang, hardware, software, jaringan komunikasi, serta sumber daya data yang dikumpulkan, diubah serta disebarkan ke sebuah organisasi dalam bentuk informasi [1].

\subsection{E-Voting}

Voting secara sederhana dapat diartikan sebagai tindakan memilih menggunakan hak pilih dalam sebuah kegiatan pemilihan umum. Voting berkaitan dengan proses pemilihan seorang pemimpin yang menurut mereka seseorang tersebut paling mewakili suara mereka. Sedangkan yang dimaksud dengan E-voting, secara sederhana menggunakan hak pilih dalam kegiatan pemilu dengan bantuan teknologi yaitu secara digital elektronik [3].

\subsection{Codeigniter}

Codeigniter merupakan sebuah Web framework yang dirancang untuk menjadikan sebuah Web framework ringan, cepat, handal dan mudah digunakan [2]. Framework Codeigniter ini dipilih karena mempunyai beberapa keunggulan sebagai berikut:

a) Free, Codeigniter merupakan framework yang berada dibawah lisensi open source yang dapat melakukan apapun terhadap framework ini.

b) Fast, berdasarkan dokumentasi performa yang dimiliki terbukti lebih cepat dibandingkan dengan framework lainya.

c) Menggunakan konsep MVC, dengan menggunakan konsep model, view, controller, kita dapat memisahkan bagian logic dan presentation dari aplikasi yang dibuat supaya mempermudah programmer hanya fokus ke dalam pembangunan logic sedangkan desainer berfokus pada template file.

d) Menghasilkan URL yang bersih. URL yang dihasilkan bersih dan ramah terhadap mesin pencari. 


\section{PEMBAHASAN}

\subsection{Analisis Sistem}

Dalam analisis sistem ini, peneliti melakukan pengumpulan data melalui interview dengan user atau custamer yang akan mempergunakan sistem yang dirancang. Seorang analis akan berkomunikasi dengan pengguna secara intensif agar dapat membangun sebuah sistem yang diharapkan oleh pengguna dan menjawab permasalahan yang dihadapi. Pada tahapan ini akan menentukan tujuan umum serta tahapan spesifikasi apa yang diinginkan pengguna dalam bentuk dokumen user requirement atau data yang berhubungan dengan keinginan pengguna. Metode prototipe merupakan metode yang berulang, yang artinya tahapan ini akan berulang sampai kedua belah pihak mencapai kesepakatan.

\subsection{Desain Sistem}

Pada tahapan ini proses perancangan dibuat dengan cara mendesain secara umum yang nantinya akan dikembangkan kembali. Pada tahap ini proses perancangan dilakukan dengan menggunakan permodelan masalah yang menggunakan analisa berorientasi objek dengan diagramdiagram dalam UML. Diagram tersebut antara lain diagran use case, diagram sekuen, diagram akrivitas dan sebagainya. Berikut ini adalah gambar diagram dari rancangan sistem E-Voting.

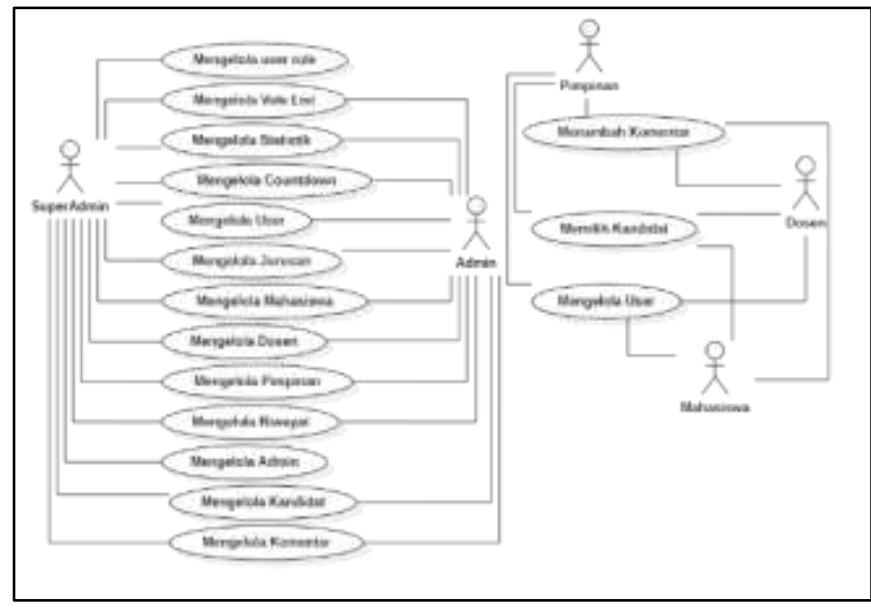

Gambar 2. Use Case Diagram sistem

Pada Gambar 2 di atas ditunjukan perancangan sistem menggunakan diagram use case. Diagram ini menunjukan sebuah diagram umum yang mempunyai lima aktor di dalamnya, yaitu SuperAdmin, Admin, Pimpinan, Dosen dan Mahasiswa. 


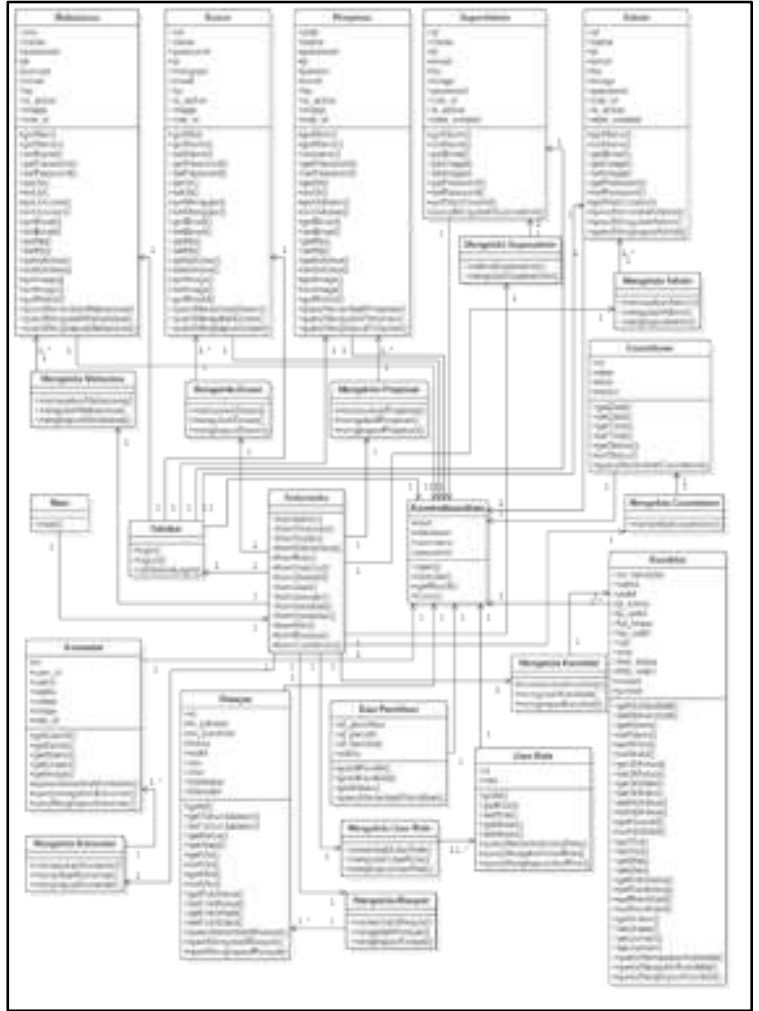

Gambar 3. Class Diagram

Pada gambar 3 di atas kita bisa melihat diagram objek yang mempunyai kesamaan dengan diagram kelas yang menjelaskan tentang objek atribut yang terdapat di dalam database serta mejelaskan fungsi - fungsi yang dapat dilakukan oleh setiap objek.

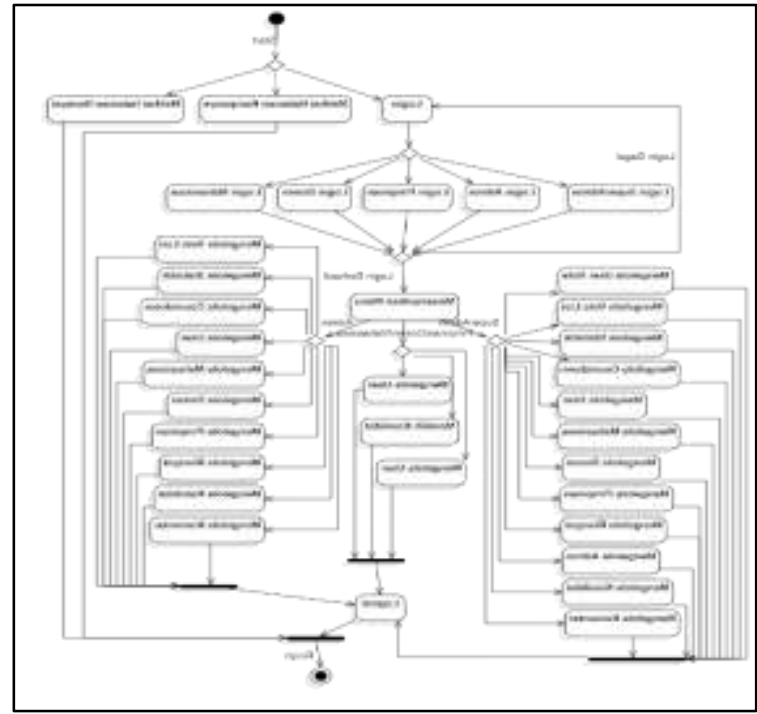

Gambar 4. Activity Diagram

Gambar 4 merupakan diagram yang menggambarkan aktifitas yang dapat dilakukan oleh user. User dapat memilih aktifitas apa yang diinginkan yaitu dapat melihat halaman riwayat, kampanye dan melakukan login. Ketika user melakukan login, akan diberi sebuah pilihan dimana pilihan tersebut adalah login (sesuai dengan status user). Setelah login, akan dihadapkan dengan sebuah halaman sesuai dengan status user. 


\subsection{Pengujian Sistem}

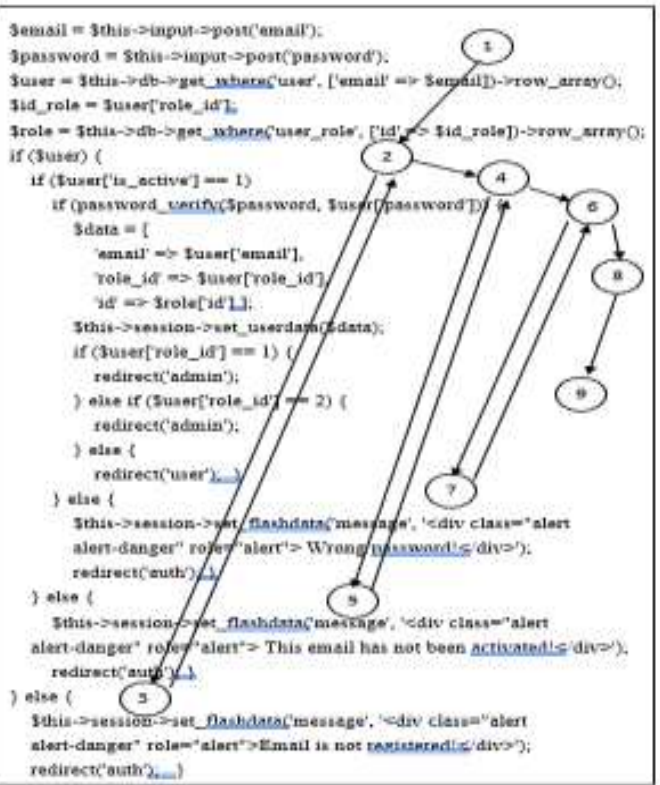

Gambar 5. White Box Testing Login Flowchart

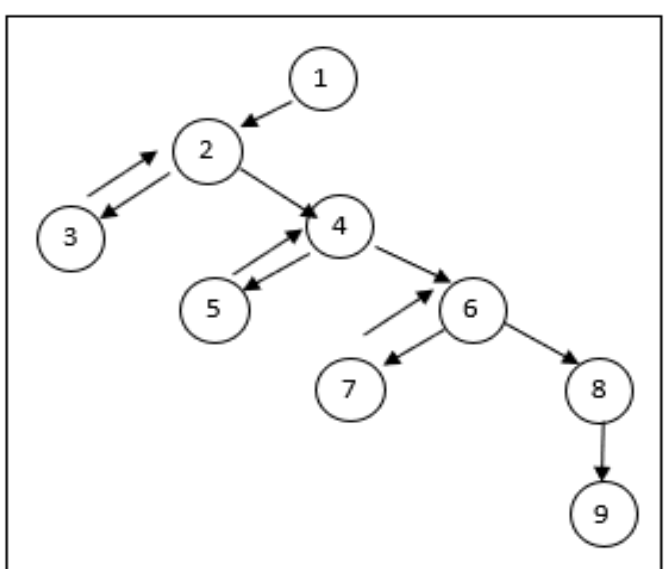

Gambar 6. Flowgraph Proses Login

Pada gambar flowgraph di atas dapat dihitung kompleksitas cyclomatic proses dengan menggunakan rumus : $\mathbf{V}(\mathbf{G})=\mathbf{E}-\mathbf{N}+\mathbf{2}$

$\mathrm{V}(\mathrm{G})$ : cyclomatic complexity

$\mathrm{E} \quad$ : total jumlah $e$ dge

$\mathrm{N} \quad$ : total jumlah node

Dapat dihitung sebagai berikut :

$\mathrm{V}(\mathrm{G})=11-9+2$

$\mathrm{V}(\mathrm{G})=4$

Dari hasil perhitungan cyclomatic complexity di atas menunjukan jumlah pengujian yang harus dijalankan dengan path sebagai berikut

Path 1 : 1-2-4-6-8-9

Path 2 : 1-2-4-6-7-6-8-9

Path 3 : 1-2-4-5-4-6-7-8-9

Path 4 : 1-2-3-2-4-5-6-7-8-9

Jika semua data dimasukan dengan benar, maka jalur terpendek yang akan dilalui pada path 1 . 
JEC Vol. 6 No. 2

Jurnal Electro Luceat [November $][2020]$

Tabel 1. Black Box Testing

\begin{tabular}{|c|c|c|c|c|c|c|}
\hline Denkripn & Tent Con & IFyut & $\begin{array}{l}\text { Output } \\
\text { yang } \\
\text { bonar }\end{array}$ & $\begin{array}{l}\text { Kriterita } \\
\text { Naleati }\end{array}$ & Cutpent & $\begin{array}{l}\text { Kenimpe } \\
\text { Lan }\end{array}$ \\
\hline Uji lagin & 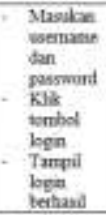 & $\begin{array}{l}\text { Crema } \\
\text { me. } \\
\text { Pasure } \\
\text { rd }\end{array}$ & 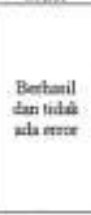 & 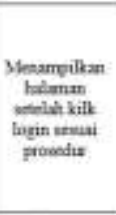 & $\begin{array}{l}\text { Tidsk ads } \\
\text { yang aror }\end{array}$ & Bethasiil \\
\hline $\begin{array}{c}\text { Cdk } \\
\text { login } \\
\text { wemamo } \\
\text { valah }\end{array}$ & 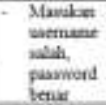 & 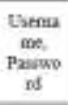 & $\begin{array}{l}\text { Terdapat } \\
\text { perapran } \\
\text { weename } \\
\text { salat }\end{array}$ & 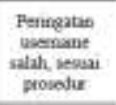 & 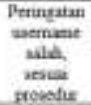 & Betsail \\
\hline $\begin{array}{c}\text { cok } \\
\text { login } \\
\text { passurod } \\
\text { salah }\end{array}$ & 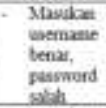 & $\begin{array}{l}\text { Csemia } \\
\text { me. } \\
\text { Pagson } \\
\text { of }\end{array}$ & $\begin{array}{l}\text { Tedtagut } \\
\text { peringstan } \\
\text { passwowd } \\
\text { salah }\end{array}$ & $\begin{array}{l}\text { Peringazan } \\
\text { passmord } \\
\text { salah, vesuai } \\
\text { prosodur }\end{array}$ & 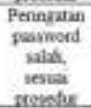 & Berbasil \\
\hline 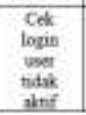 & 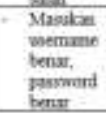 & $\begin{array}{l}\text { Chems } \\
\text { me } \\
\text { Panwo } \\
\text { nd }\end{array}$ & 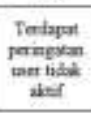 & 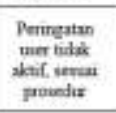 & 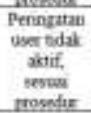 & Dertasil \\
\hline
\end{tabular}

\subsection{Uji Manfaat}

Berikut ini adalah hasil data SPSS Kuesioner pada uji manfaat

Tabel 2. Tabulasi Hasil

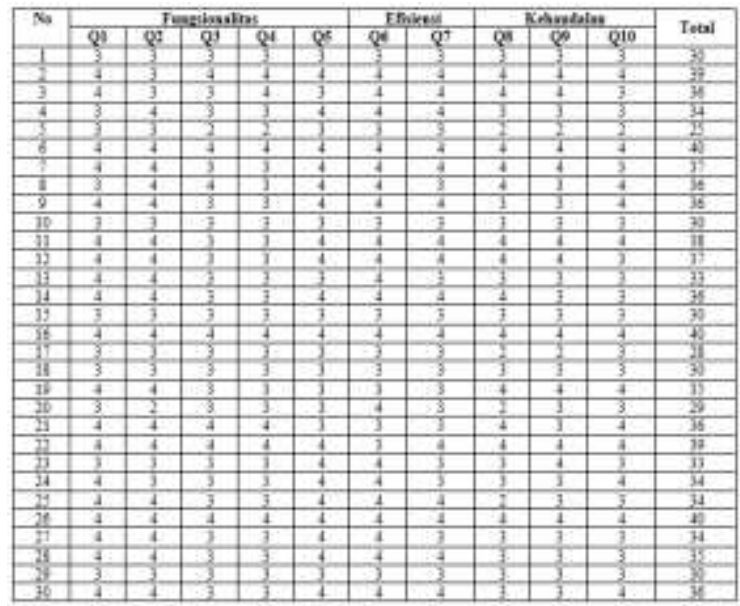

\subsection{Interpretasi Hasil}

Tabel 3. Rata - Rata Hasil Uji Manfaat

\begin{tabular}{|c|c|c|c|c|c|}
\hline \multirow{7}{*}{ Fungsionalitas } & \multirow{2}{*}{ Pertanyaan } & \multicolumn{2}{|c|}{ Kriteria } & \multirow{2}{*}{ Total } & \multirow{2}{*}{ Rata-rata } \\
\hline & & SS & $\mathrm{S}$ & & \\
\hline & 1 & 63,3 & 36,7 & 100 & \multirow{5}{*}{97,98} \\
\hline & 2 & 60 & 36,7 & 96,7 & \\
\hline & 3 & 23,3 & 73,3 & 96,6 & \\
\hline & 4 & 23,3 & 73,3 & 96,6 & \\
\hline & 5 & 60 & 40 & 100 & \\
\hline \multirow{4}{*}{ Efisiensi } & \multirow{2}{*}{ Pertanyaan } & \multicolumn{2}{|c|}{ Kriteria } & \multirow{2}{*}{ Total } & \multirow{2}{*}{ Rata-rata } \\
\hline & & SS & $\mathrm{S}$ & & \\
\hline & 1 & 66,7 & 33,3 & 100 & \multirow{2}{*}{100} \\
\hline & 2 & 50 & 50 & 100 & \\
\hline \multirow{5}{*}{ Kehandalan } & \multirow{2}{*}{ Pertanyaan } & \multicolumn{2}{|c|}{ Kriteria } & Tota1 & \multirow{2}{*}{ Rata-rata } \\
\hline & & SS & $\mathrm{S}$ & lotal & \\
\hline & 1 & 43,3 & 43,3 & 86,6 & \multirow{3}{*}{92,23} \\
\hline & 2 & 36,7 & 56,7 & 93,4 & \\
\hline & 3 & 40 & 56,7 & 96,7 & \\
\hline
\end{tabular}




\section{KESIMPULAN}

Dari penelitian yang berjudul Sistem Informasi Pemilihan (E-Voting) Ketua dan Wakil Ketua Senat Mahasiswa Berbasis Web Menggunakan Framework Codeigniter studi kasus di Stikom Yos Sudarso Purwokerto, dapat disimpulakan bahwa sistem ini dapat membantu perhitungan rekapitulasi dengan cepat. Hal tersebut dapat dibuktikan bedasarkan hasil uji hipotesis dimana terdapat perbedaan waktu menghitung rekapitulasi sebelum dan sesudah menggunakan Sistem Informasi ini.

Sistem ini dapat bermanfaat dalam hal fungsionalitas, efisiensi dan kehandalan yang dibuktikan berdasarkan tabel rata-rata pengujian manfaat dari jawaban reponden memilih kriteria sangat setuju dan setuju, dimana nilai fungsionalitasnya adalah $97,8 \%$, nilai efisiensi adalah $100 \%$ dan nilai kehandalan adalah 92,23.

Dengan demikian, secara keseluruhan dapat disimpulkan bahwa Sistem Informasi Pemilihan (E-Voting) untuk pemilihan Ketua dan Wakil Ketua Senat Mahasiswa Berbasis Web Menggunakan Framework Codeigniter studi kasus di Stikom Yos Sudarso Purwokerto dapat digunakan secara efektif dan efisien.

\section{DAFTAR PUSTAKA}

[1] Anggraeni, E. y. \& Irviani, R., 2017. Pengantar Sistem informasi. Yogyakarta: CV. ANDI OFFSET.

[2] Anton Subagio, 2017. Membangun aplikasi dengan Codeigniter dan Database SQL Server. Jakarta: PT Alex Media Komputindo.

[3] Darmawan, I., Nurhandjati, N. \& Kartini, E., 2014. Memahami E-voting Berkaca dari Pengalaman Negara-negara Lain dan Jembrana (Bali). Jakarta: Yayasan Pustaka Obor Indonesia.

[4] Fifiana W dan I'ib Sutera A. P. 2020. Dampak Pandemi Covid-19: Modernisasi Dan Digitalisasi Komisi Pemilihan Umum Republik Indonesia (Kpu-Ri). Jurnal Ilmiah Galuh Justisi. 8:2 196-203

[5] Fitri Oviyanti. 2016. Peran Organisasi Kemahasiswaan Intrakampus dalam Mengembangkan Kecerdasan Interpersonal Mahasiswa. Jurnal of Islamic Education Management. 2:1 61-79

[6] Muslihudin, M., 2016. ANALISIS dan Perancangan Sistem Informasi Menggunakan Model Terstuktur dan UML. Yogyakarta: CV ANDI OFFSET.

[7] Pratama, I. P. A. E., 2014. Sistem Informasi dan Implementasinya. bandung: Informatika Bandung. 